\title{
LARGE-LEAVED LUPIN (Lupinus polyhyllus Lind.) AND EARLY RED CLOVER (Trifolium pratense L.) AS GREEN MANURE GROPS
}

\author{
Enn Lauringson, Liina Talgre, and Arvo Makke \\ Institute of Agricultural and Environmental Sciences, Estonian University of Life Sciences, \\ Kreutzwaldi 1, Tartu 51014, ESTONIA \\ enn.lauringson@emu.ee
}

Communicated by Isaak Rashal

\begin{abstract}
Trials with large-leaved lupine ('Lupi') and early red clover ('Jõgeva 433') as green manure were carried out to study their suitability for green manure production. The trials were carried out on the trial fields of the Estonian University of Life Sciences in 2008-2010. Biomass production abilities of various plants grown with or without a cover crop were examined. In the experiment, different green manure crops with undersowing and pure sowing were compared for amounts of $N, C, P, K$ and organic matter driven into soil and their effect on cereal yield. The value of these green manure crops as manure was estimated, based on their effect on the succeeding cereal yield. From green manure plants, sown with cover crops, red clover gave the best results, while large-leaved lupine was better grown as pure crop (18\% more biomass than red clover in similar situation). Biomass from large-leaved lupine, grown without cover crop, was also the most efficient in returning nutrients into the soil. Pure green manure had bigger effect and it lasted longer if grown as undersowing.
\end{abstract}

Key words: green manure, biomass, large-leaved lupine, red clover, nutrient binding.

\section{INTRODUCTION}

Soil analyses from preceding years demonstrate that many Estonian farmers have a negative humus balance in their crop rotations. Humus content can be positively influenced with agrotechnical methods, most important of which is proper crop constitution in crop rotation systems and skilled use of organic fertilisers.

Organic matter that has been added to soil improves its humus conditions, thereby improving soil's nutrition regimen and hydrophysical characteristics (Reeves, 1997). As plant remains that are not decomposed (or are semi-decomposed) mineralise, practically all nutrients needed for plant growth are seasonally released. Humus material acts as a growth stimulator for higher plants, it also improves nutrient availability for roots. Plentiful introduction of organic matter to soil has a positive effect on soil ecosystems and biological activity.

In favourable conditions, legumes as green manure crops can produce up to 8-10 tonnes of dry matter per hectare (Talgre et al., 2009; Dubrovskis et al., 2011; Talgre et al., 2012). This amount of dry matter adds up to $300 \mathrm{~kg} \mathrm{ha}^{-1}$ of nitrogen to soil. Green manure crops not only increase soil $\mathrm{N}$ content, they also influence its depth in soil. The effect of green manure on succeeding crops is therefore related to the depth of the succeeding plant's root system.

Red clover and white melilot are the most popular green manure crops in Estonia, but large-leaved lupin is also becoming increasingly popular. The latter is also a good bioenergy crop, due to its stable and abundant biomass, and some cultivars can also be used as fodder. Large-leaved lupin is well adapted to Finnish and North-West Russian conditions (Kurlovich et al., 2008) and also in Belarus and Latvia. Large-leaved lupin can be cultivated on low-fertile sandy and acid soils, unprofitable for cultivating other crops (Dubrovskis et al., 2011). In Estonia, the cultivar 'Lupi' was bred especially for use as a green manure crop. Its alkaloid content was considered irrelevant by the breeders, since alkaloid content has no significant effect when the crop is used as green manure (Bender, 2012).

It is also necessary to take into account that lupin's deeper roots survive autumn ploughing and that lupin plants may start spoiling of successor crops (Lauringson et al., 2011; Bender, 2012).

Driven by interest shown by agricultural producers, the Estonian University of Life Sciences established a research programme in 2008 to examine large-leaved lupin from the perspective of using it as a green manure crop. 


\section{MATERIAL AND METHODS}

The research was established in 2008 on sandy loam Stagnic Luvisol (according to the WRB 2006 classification) with the following characteristics in its humus layer: $1.1-1.2 \% \mathrm{C}_{\text {org }}, 0.10-0.11 \% \mathrm{~N}_{\text {tot }}, 5.5-10 \mathrm{mg} 100 \mathrm{~g}^{-1} \mathrm{P}$,

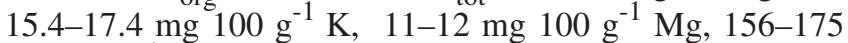
mg $100 \mathrm{~g}^{-1} \mathrm{Ca}$ (P and $\mathrm{K}$ measured with AL method), $\mathrm{pH}_{\mathrm{KCl}}$ $5,6-5,8$. Thickness of humus layer was $27-29 \mathrm{~cm}$ and density $1.40-1.55 \mathrm{mg} \mathrm{m}^{-3}$.

The following trials were carried out:

a) green manure legumes without cover crop (red clover 'Jõgeva 433', large-leaved lupine 'Lupi');

b) legume green manure crops as barley undersows (red clover, large-leaved lupine). Barley 'Inari' with seeding norm 500 germinating seeds $\mathrm{m}^{2}$ as a cover crop;

c) unfertilised barley (control trial) and barley with mineral fertiliser (N 50 and $\mathrm{N} 100 \mathrm{~kg} \mathrm{ha}^{-1}$ ).

Before sowing, lupine seeds were treated in the spring with soil that was taken from the lupine field of the previous year (dried and ground up soil was added to the seeds) to enrich the seeds with species-specific Rhizobia.

In all trials, the resulting biomass was ploughed into soil in the third decade of October. In 2009, summer wheat 'Trappe' and in 2010, barley 'Inari', were grown as succeeding crops with seeding norm 500 germinating seeds $\mathrm{m}^{2}$.

Analogous trials were established also in 2009 and 2010. In the trial established in 2009 the succeeding crop was also summer wheat 'Trappe'. The 2010, only green manure biomass was measured, and the trial was not followed by a cereal as a succeeding crop. Red clover without a cover crop was sowed with a $15 \mathrm{~kg} \mathrm{ha}^{-1}$ seed norm. As several producers have used undersows with decreased seed norms, also a red clover crop with smaller seed norm $-7.5 \mathrm{~kg} \mathrm{ha}^{-1}$ was used in the trial with a cover crop. The large-leaved lupine's seed norm was based on Tupits (1954) recommendations: large-leaved lupine with cover crop had $30 \mathrm{~kg} \mathrm{ha}^{-1}$ and without cover crop $40 \mathrm{~kg} \mathrm{ha}^{-1}$, respectively. Seed row gap was $12.5 \mathrm{~cm}$ for both cereals and legumes.

The trials were started using a Wintersteiger sowing machine for spreading cereal and grass seeds. On the second and third year, cereals were sown with a Kongskilde sowing machine. Cereal crops were harvested with a Sampo research combine. The straw was shredded with a combine while harvesting; green manure was ground in the third decade of October with a Müthing mower.

Samples for measuring biomass in cereal pure sows were collected before harvests and root mass was weighed for up to $60 \mathrm{~cm}$ depth. In undersow variants, the biomass from green manure crops was measured twice: first during the harvest and second, before the autumnal ploughing. Biomass and root mass of legume crops without cover crops were measured in the second decade of October. Dry matter yield (shoots, roots, and weeds) was measured.

Stubble without undersow, straw and green manure were ploughed up to $23-25 \mathrm{~cm}$ depth. Samples of plant material were air-dried and ground. Acid digestion by sulphuric acid solution was used to determine $\mathrm{P}$ and $\mathrm{K}$ content in plant material. Total $\mathrm{N}$ and $\mathrm{C}$ content of oven-dried samples were determined by dry combustion method on a varioMAX CNS elemental analyser (ELEMENTAR, Hanan, Germany).

The experimental area belongs to the South-Estonian upland agroclimatic region. During the experimental period, rainfall and air temperature were recorded daily at a meteorological station located within the experimental area (Table $1)$.

Table 1

WEATHER CONDITIONS OF 2008-2010 (ACCORDING TO THE ERIKA WEATHER STATION) AND THE AVERAGE VALUES IN 1966-1998* IN TARTU ${ }^{1}$

\begin{tabular}{l|c|c|c|c|c|c|c|c}
\hline \multirow{2}{*}{ Month } & \multicolumn{4}{c}{ Air temperatures, ${ }^{\circ} \mathrm{C}$} & \multicolumn{4}{c}{ Precipitation, mm } \\
\cline { 2 - 9 } & 2008 & 2009 & 2010 & $\begin{array}{c}\text { Aver- } \\
\text { age* }\end{array}$ & 2008 & 2009 & 2010 & $\begin{array}{c}\text { Aver- } \\
\text { age* }\end{array}$ \\
\hline January & -1.3 & -3.4 & -12.7 & -7.1 & 22 & 10 & 5 & 29 \\
February & 0.6 & -4.9 & -7.9 & -6.6 & 34 & 7 & 5 & 23 \\
March & 0.4 & -1.5 & -2.1 & -2.4 & 8 & 22 & 30 & 26 \\
April & 7.1 & 5.3 & 6.1 & 4.2 & 27 & 14 & 26 & 33 \\
May & 10.6 & 11.5 & 12.6 & 11.6 & 27 & 13 & 61 & 55 \\
June & 14.4 & 13.8 & 14.6 & 15.1 & 110 & 137 & 73 & 66 \\
July & 16.1 & 16.9 & 22.2 & 16.7 & 54 & 55 & 36 & 72 \\
August & 17.7 & 15.4 & 18.2 & 15.6 & 118 & 89 & 107 & 79 \\
September & 9.8 & 12.8 & 11.1 & 10.4 & 46 & 49 & 93 & 66 \\
October & 8.2 & 4.1 & 12.4 & 5.7 & 68 & 116 & 49 & 52 \\
November & 2.3 & 2.3 & 0.8 & 0.3 & 49 & 36 & 53 & 48 \\
December & -1.1 & -3.8 & -7.7 & -4.2 & 24 & 41 & 17 & 40
\end{tabular}

1 Jaagus, 1999

The software STATISTICA 10 (StatSoft Inc., Tulsa, USA) was used for the statistical data analysis. The variations between trials are shown as standard deviations (biomass) and $\mathrm{LSD}_{0.05}$ (harvest from succeeding crops).

\section{RESULTS}

Biomass yield. The amount of biomass that was added to soil by barley undersows was 4.28-5.70 $\mathrm{t} \mathrm{ha}^{-1}$ in 2008; $25-36 \%$ of that consisted of roots. Of all legume crops, red clover as undersow produced the biggest amount of above ground biomass. Lupine, when grown as cereal undersow, produced clearly less herbage and aftermath than red clover in the same conditions. Pure green manure crops of legumes added $7 \mathrm{t}$ of biomass per hectare; $40-44 \%$ of that consisted of roots. Depending on how much nitrogen fertiliser was applied, in 2009 autumn ploughing after barley sows added 3.50-5.32 $\mathrm{t} \mathrm{ha}^{-1}$ organic matter to soil (measured as dry matter). This included $1.22-1.83 \mathrm{t}$ straw and $0.31-0.59 \mathrm{t}$ 
weeds. In pure barley sows, 34-35\% of resulting biomass was roots (Fig. 1).

In 2009 , lupine early growth was much faster than in 2008, and therefore, biomass of lupine herbage under the cover crop and its aftermath were both comparable with the red clover results. With undersows, red clover added $7.2 \mathrm{t} \mathrm{ha}^{-1}$ and large-leaved lupine added $6.40 \mathrm{t} \mathrm{ha}^{-1}$ biomass to soil.

The largest amount of biomass $\left(8.59 \mathrm{t} \mathrm{ha}^{-1}\right)$ in this experiment was obtained when large-leaved lupine was sown without a cover crop. Red clover produced $5.74 \mathrm{t} \mathrm{ha}^{-1}$ in this setting. Biomass from these leguminous grasses contained $51-56 \%$ roots.

Due to exceptionally warm weather in July and first half of August in 2010, many crops suffered from drought, which also had on impact on biomass production of pure legume sows. In barley sows, soil received about 2.82-3.80 $\mathrm{t} \mathrm{ha}^{-1}$ biomass from straw and roots. Red clover undersows added $8.36 \mathrm{t} \mathrm{ha}^{-1}$ organic matter to soil.

Whole biomass from large-leaved lupine undersow was about $5.53 \mathrm{t} \mathrm{ha}^{-1}$ and contained $46 \%$ roots. Large-leaved lu-
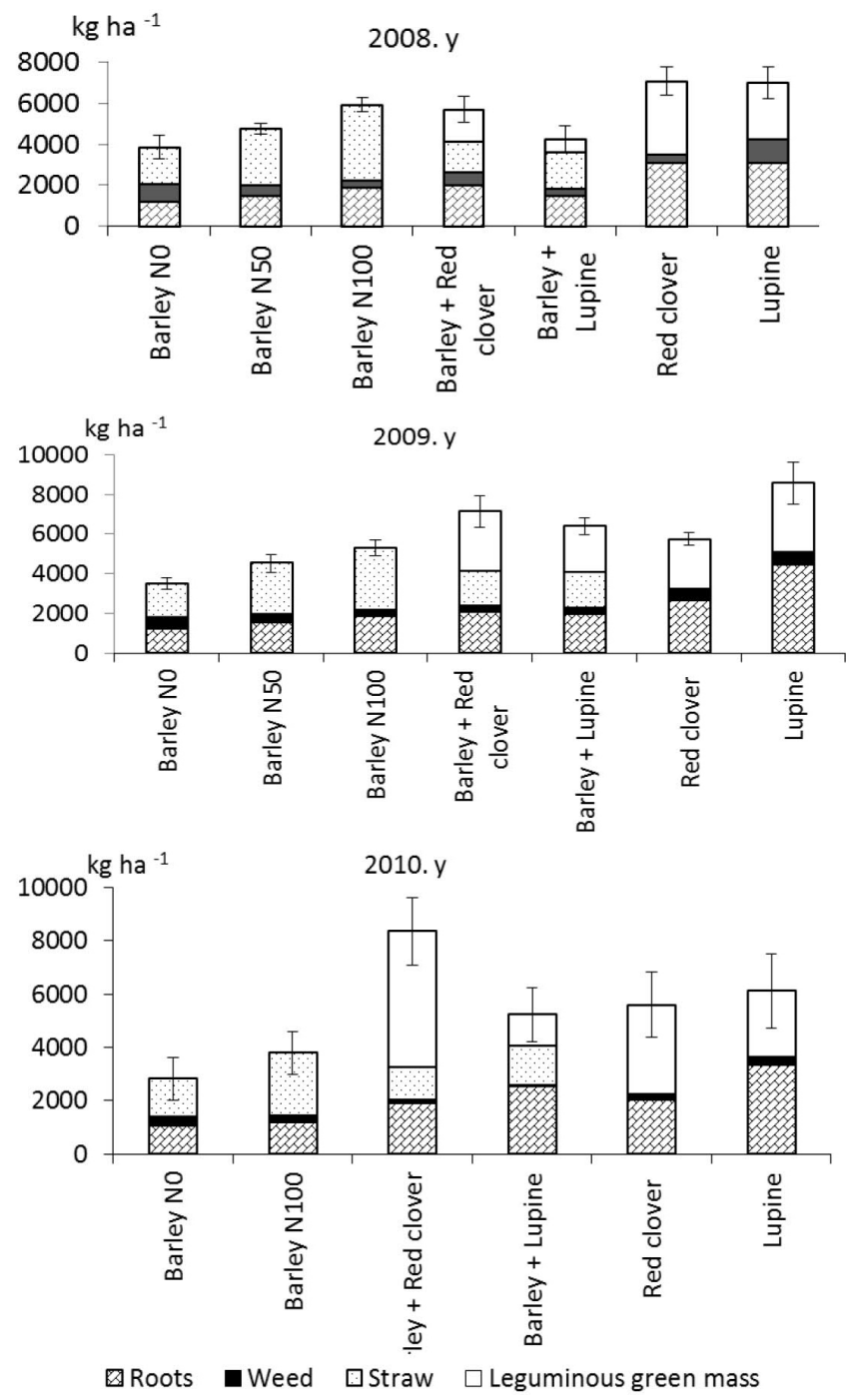

Fig. 1. Added biomass and its composition in 2008-2010. Data as average from four replications \pm standard deviation. pine also produced a relatively high amount of biomass from pure sow $\left(6.13 \mathrm{t} \mathrm{ha}^{-1}\right)$ with $54 \%$ roots.

Additional soil nutrients from biomass. Depending on yield, in the first year barley grains removed $25-59 \mathrm{~kg} \mathrm{~N}$, 6-14 kg P and 11-35 kg K per hectare from soil. The amount of nutrients that was returned to soil with biomass varied greatly.

In 2008, barley straw and roots returned 1.61-2.52 t C, 33-48 kg N, 7-10 kg P and 48-75 kg K per hectare. The $\mathrm{C} / \mathrm{N}$ ratio in the organic matter varied between $49-56$. Legume undersows returned 1.77-2.71 t C, 68-99 kg N, 9-14 $\mathrm{kg} \mathrm{P}$ and $62-107 \mathrm{~kg} \mathrm{~K} \mathrm{ha}^{-1}$, while the $\mathrm{C} / \mathrm{N}$ ratio in biomass was between 23-35. Biomass from legume pure sows returned 2.78-2.89 t C, 139-148 kg N, 19-21 kg P and 115-133 kg K ha ${ }^{-1}$; C/N ratio 19-20 (Fig. 2).

In 2009, barley straw and roots, depending on nitrogen fertiliser amounts, added $1.45-2.21 \mathrm{t} \mathrm{C}, 28-42 \mathrm{~kg} \mathrm{~N}, 5-8 \mathrm{~kg} \mathrm{P}$ and $45-74 \mathrm{~kg} \mathrm{~K}$ per hectare. Barley biomass $\mathrm{C} / \mathrm{N}$ ratio was 52-55.

Biomass from legume undersows added 2.48-3.74 t C, 131-224 kg N, 15-27 kg P and 108-147 kg K per hectare, with $\mathrm{C} / \mathrm{N}$ ratio $17-19$.
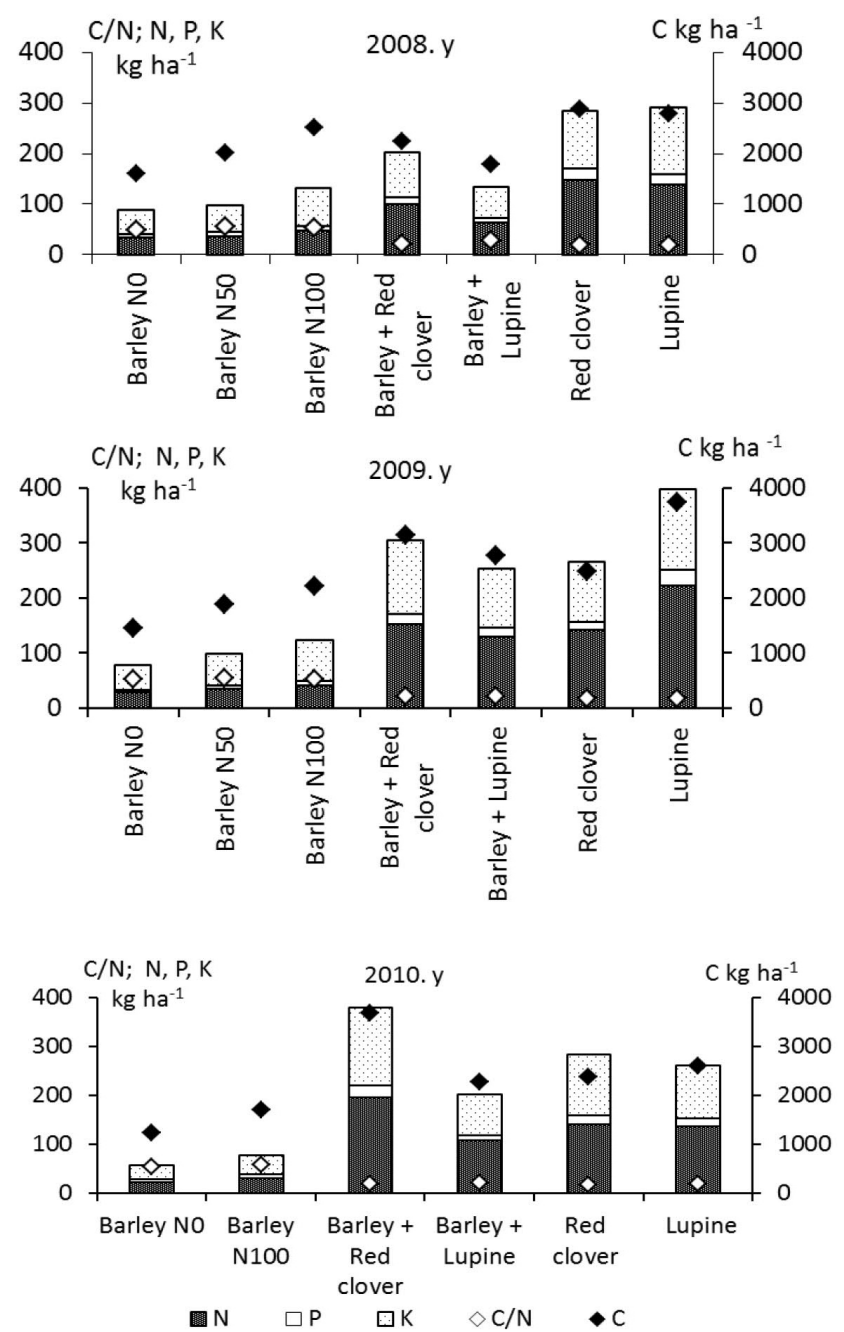

Fig. 2. Nutrients returned to soil by biomass 2008-2010. 


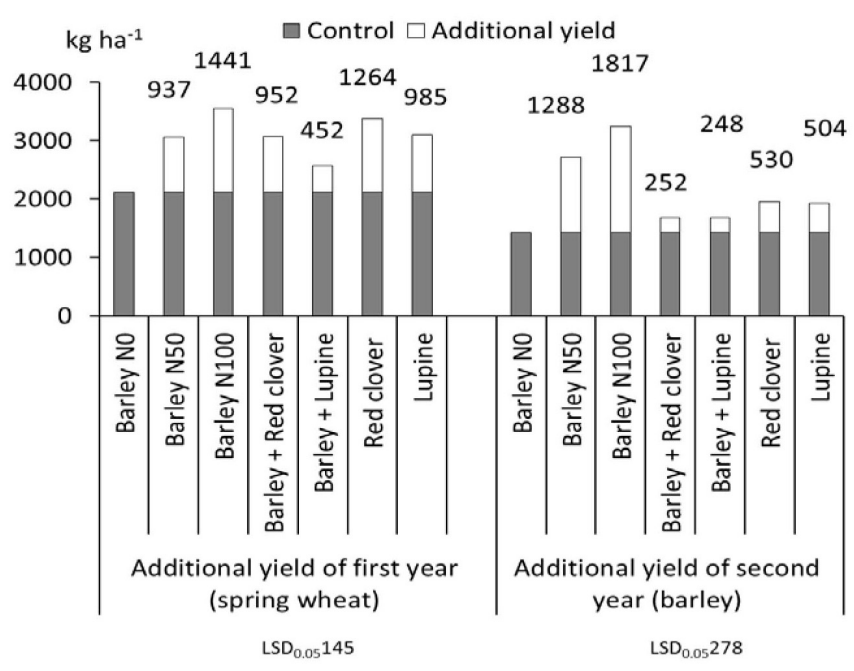

Fig. 3. Yield increase of succeeding crops $\left(\mathrm{kg} \mathrm{ha}^{-1}\right)$ depending on green manure application compared with unfertilised cereal.

In 2010, biomass from red clover variants with and without cover crop returned the highest amounts of nutrients to soil: 142-197 kg N, 18-23 kg P ja 124-160 kg K per hectare. The biomass added 2.37-3.68 $\mathrm{t} \mathrm{ha}^{-1} \mathrm{C}$, while the $\mathrm{C} / \mathrm{N}$ ratio was 17-19. Biomass from large-leaved lupine undersows and pure sows added 107-136 kg N, 12-17 kg P and 83-108 kg K and 2.28-2.61 t ha ${ }^{-1} \mathrm{C}$; C/N ratio $19-21$.

Barley straw and roots added to soil 1.24-1.69 t C, 23-30 $\mathrm{kg} \mathrm{N}, 5-8 \mathrm{~kg} \mathrm{P}$ and $29-40 \mathrm{~kg} \mathrm{~K}$ per hectare with the $\mathrm{C} / \mathrm{N}$ ratio 54-57.

Effect of green manure on succeeding crop yield. Green manure that was ploughed into soil in the autumn of the growth year increased the succeeding summer wheat crop yield in the next year. Compared to the control variant, ploughed in biomass from pure red clover sow had the biggest effect. In the second year, the succeeding crop was barley and the effect of green manure was noticeable only in the pure legume sow variant. A year later, effects of legume undersows and pure sows on crop had become similar (Fig. 3).

\section{DISCUSSION}

When lupine is grown as a cereal undersow, its biomass amount depends on aftermath growth. In 2008, lupine did not produce much aftermath. This was probably caused by an unusually rainy harvest period and a delayed cereal harvest. In contrast, in 2010, the cover crop could be harvested in early August and the following good growth period produced lots of aftermath. Red clover produced more aftermath (4.04 $\mathrm{t}$ dry matter $\mathrm{ha}^{-1}$ ) than lupine. As an average, in our trials pure large-leaved lupine sows produced $18 \%$ more biomass than red clover. This is in accordance with other studies (Bender 2012; 2013) where in pure legume sow, red clover made up $61.3 \%$ and in undersow $54.8 \%$ of largeleaved lupine biomass.
Our study showed that legume green manure crops bind large amounts of phosphorus and most of the potassium for biological cycles every year. Harvesting may have a detrimental effect on soil quality, especially in organic farming and on low nutrition soils, which may become too poor in nutrients. As soil phosphorus and potassium contents decrease, so does its ability to bind nitrogen biologically. Deep-rooted legumes are able to utilise nutrients from lower humus layers, and if their organic matter is ploughed in, nutrient quality in the arable layer improves. Considering that an average of $80 \%$ of the roots are situated in the ploughed layer (Freyer, 2002), it may be assumed that approximately $80 \%$ of the fixed $\mathrm{P}$ and $\mathrm{K}$ are derived from the humus layer and the remainder from deeper soil layers. In order to increase phosphorus or potassium content in the plough layer to $5 \mathrm{mg} \mathrm{kg}^{-1}$, it is necessary to add $20 \mathrm{~kg} \mathrm{ha}^{-1}$ for these nutrients. (Lauringson et al., 2011). This means that growing legumes as a green manure crop for a short time does not have any significant effect on soil nutritional qualities; their regular use in crop rotation is needed to improve plant nutrition. It should also be taken into consideration that legume cultures utilise less soluble phosphorus and potassium, leaving them available for other crops, if legume biomass is ploughed into soil (Maiksteniene and Arlauskiene, 2004).

Organic decomposition of organic matter in soil greatly depends on its $\mathrm{C} / \mathrm{N}$ ratio (Gunnarsson and Marstrop, 2002; Trinsoutrot et al., 2002). The narrower the $\mathrm{C} / \mathrm{N}$ ratio in organic matter and the more nitrogen in soil, the more nitrogen is released to soil through biomass mineralisation. In barley straw, the $\mathrm{C} / \mathrm{N}$ ratio was $50-60$, campared to $12-18$ in the biomass of above ground parts of legume crops. This shows that growing legumes as undersows improves the $\mathrm{C} / \mathrm{N}$ ratio in organic matter, which creates better conditions for straw decomposition in soil, and also decreases the amount of nitrogen that is fixed by soil microorganisms.

The current research was carried out on soils that were low in humus and nitrogen, which meant that mineral nitrogen fertilisers were more effective than usual. Green manure that was added to soil either from undersow or pure sow, increased summer wheat yield in the following year by up to $60 \%$, compared with fields that were not fertilised with nitrogen. The positive after effect was still noticeable in the second year, but only from pure legume sows. Our earlier research (Talgre et al., 2012) showed that legumes still had a positive effect even in the third year after they were ploughed in. According to Bender (2012), large-leaved lupine biomass, when ploughed into soil in the autumn of the sowing year, increased next summer wheat yield by $23 \%$. A year later, barley yield was $26.8 \%$ higher in the same field and $10 \%$ higher in the year after that. Besides yield, grain quality also improved. Earlier research showed that 72-84\% of the green manure effect occurs in first year and 16-18\% in the second year (Viil and Võsa, 2005). Our experiments with various legumes (from 2004 till 2010) showed that the efficiency of green manure-derived nitrogen on cereal yield depended on the amount of nitrogen that was returned to soil from biomass. In the first year, green manure nitrogen 
produced $11.8 \mathrm{~kg}$ grain per $\mathrm{N} \mathrm{kg}$. In the second year, it was $4.2 \mathrm{~kg}$ grain per $\mathrm{N} \mathrm{kg}$ and only $2.0 \mathrm{~kg}$ grain per $\mathrm{N} \mathrm{kg}$ (Lauringson et al., 2011).

In conclusion, pure legume sows produced more biomass with higher fertiliser qualities. On average, large-leaved lupine pure sows produced $18 \%$ more biomass than red clover (in 2009, even $49 \%$ more). Lupine can be successfully used as a means of increasing fertility of poor sandy soils, as it can enrich the soil with up to $224 \mathrm{~kg} \mathrm{ha}^{-1}$ of nitrogen.

When using undersows as green manure, red clover produced the most stable amount of biomass. Competition within the cover crop competitiveness had the biggest effect on lupine growth and ability to form biomass. Therefore, when large-leaved lupine is used as an undersow, the cover crop should be sown less densely.

\section{ACKNOWLEDGEMENTS}

The present study was supported by the Ministry of Agriculture of the Republic of Estonia within the framework of project "Researching methods of regulating humus status and nutrient balance of soil and phytoproductivity of various green manure crops in conventional and organic farming”.

\section{REFERENCES}

Anonymous (2006). World reference base for soil resources. ftp://ftp.fao.org/docrep/fao/009/a0510e/a0510e00.pdf.

Bender, A. (2012). Fertilization value of red clover (Trifolium pratense L.), lupin (Lupinus polyphyllus Lind.) and crimson clover (Trifolium incarnatum L.). Agraarteadus, 1, 3-11 (in Estonian)

Bender, A. (2013). Fertilization value lupin Lupi, red clover Jõgeva 433 and crimson clover as green manure. Agronoomia, 82-89 (in Estonian).
Dubrovskis, V. Adamovits, A., Plume, I., Kotelenecs, V, Zabarovskis, E. (2011). Biogas production from greater burdock, largeleaf lupin and sosnovsky cow parsnip. In: Engineering from Rural Development (pp. 388-392). Jelgava.

Freyer, B. (2002). Fruchtfolgen. Eugen Ulmer GmbH \& Co. $230 \mathrm{~S}$.

Gunnarsson, S., Marstorp, H. (2002). Carbohydrate composition of plant materials determines N mineralisation. Nutr. Cycl. Agroecosyst., 62 (2), 175-183.

Kurlovich, B., Stoddard, F. L., Earnshaw, P. (2008). Potential and problems of Lupinus polyphyllus Lind. Domestigation. In: Lupins for Health and Wealth. Proceedings of the 12th International Lupin Conference 14-18 Sept. Fremantle, Western Australia. (pp. 304-307). Palta, J. A., Berger, J. D. (eds.).

Lauringson, E., Talgre, L., Roostalu, H., Makke, A. (2011). Research methods of regulating humus status and nutrient balance of soil and phytoproductivity of various green manure crops in conventional and organic farming. 78 pp. Retrieved from

http://www.pikk.ee/upload/files/Teadusinfo/Lauringson_PMaruanne.pdf. on 10 December 2012 (in Estonian).

Maiksteniene, S., Arlauskiene, A. (2004). Effect of preceding crops and green manure on the fertility of clay loam soil. Agron. Res., 2 (1), 87-97.

Reeves, D. W. (1997). The role of soil organic matter in maintaining soil quality in continuous cropping systems. Soil Till. Res., 43, 131-167.

Talgre, L., Lauringson, E., Roostalu, H., Astover, A., Makke, A. (2012). Green manure as a nutrient source for succeeding crops. Plant Soil Environ., 58, 275-281.

Talgre, L., Lauringson, E,. Roostalu, H., Astover., A, Eremeev., V, Selge, A. (2009). The effects of pure and undersowing green manures on yields of succeeding spring cereals. Acta Agricult. Scand. Sect. B. Plant Soil Sci., 59 (1), 70-76

Trinsoutrot, I., Recous, S., Bentz, B., Lineres, M., Cheneby, D., Nicolardot, B. (2000). Biochemical quality of crop residues and carbon and nitrogen mineralization kinetics under nonlimiting nitrogen conditions. Soil Sci. Soc. Amer. J., 64 (3), 918-926.

Tupits, H. (1954). Large Leaved Lupin as Green Manure. Tallinn, 29 pp. (in Estonian).

Viil, P., Võsa, T. (2005). Liblikõielised haljasväetised [Leguminous green manures]. EMVI infoleht, nr. 148. Saku. 16 pp. (in Estonian).

PLATLAPU LUPĪNA (Lupinus Polyphyllus Lind.) UN AGRĪNĀ SARKANĀ ĀBOLIN̦A (Trifolium pratense L.) izmantošana zalıēslojumam

Lai noskaidrotu sugu piemērotību zaḷmēslojumam, tika veikti pētījumi ar platlapu lupīnu ('Lupi') un agrīno sarkano āboliņu ('Jogeva 433'). Izmēǵinājumi tika iekārtoti Igaunijas dabas zinātņu universitātes pētījumu laukos 2008.-2010. gadā. Tika izvērtēta sugu spēja veidot biomasu, audzējot ar virsaugu un bez tā. Izmēgeinājumā tika salīdzināti dažādi zaḷmēslojuma augi gan pasējā, gan tīrsējā, izvērtējot augsnē atstāto N, C, P, K un organiskās vielas daudzumu un to ietekmi uz graudaugu ražu. Zaļmēslojuma vērtība tika noteikta, pamatojoties uz tā ietekmi uz nākamā gada graudaugu ražu. Izvērtējot zaḷmēslojuma augus, kas sēti pasējā, labākie rezultāti tika iegūti, izmantojot sarkano āboliṇu, bet platlapu lupīnai labāki rezultāti bija tīrsējā (par 18\% lielāka biomasa nekā sarkanajam āboliṇam līdzīgos apstākḷos). Platlapu lupīnas biomasa, kas iegūta bez virsauga, visefektīvāk nodrošināja barības vielu papildināšanu augsnē. Lielāks un ilglaicīgās zaḷmēslojuma efekts tika novērots, ja tas tika audzēts pasējā. 